\title{
Effect of diets with hydrolysed feather keratin meal on milk yield and composition in dairy cow and calf performance
}

\section{J.A. Strzetelski, J. Kowalczyk ${ }^{1}$, Katarzyna Krawczyk, S. Osięgłowski, Teofila Stasiniewicz and Elżbieta Lipiarska}

\author{
Research Institute of Animal Production, \\ Department of Animal Physiology and Nutrition \\ 32-083 Balice, Poland \\ 'The Kielanowski Institute of Animal Physiology and Nutrition, \\ Polish Academy of Sciences \\ 05-110 Jabłonna, Poland
}

(Received 15 June 1999; accepted 7 October 1999)

\section{ABSTRACT}

The effect of hen feather keratin meals as a protein component of the diet for dairy cows on milk yield and composition (Experiment I) and on calf performance (Experiment II) was studied.

Experiment I, lasting from calving to day 84 of lactation, was carried out on 48 dairy cows divided into 4 groups fed rations containing only plant-origin feeds with (SM) or without (S) protected methionine supplement or rations containing feather keratin meal with (KM) or without (K) methionine. The proportion of keratin crude protein was about $36 \%$, and rumen undegraded keratin protein about $23 \%$ of the total crude protein of the diet. The intake of DM, UFL and average daily milk production for the entire experimental period were similar in all groups, but the intake of crude protein and intestinally digested protein in groups $\mathrm{K}$ and $\mathrm{KM}$ was higher $(\mathrm{P}<0.01)$ than in groups $\mathrm{S}$ and $\mathrm{SM}$. However, higher daily milk production was obtained between days 22 to 36 of lactation from cows receiving keratin meal $(\mathrm{P}<0.05)$ or methionine $(\mathrm{P}<0.01)$ supplements. The lactose concentration in the milk of cows receiving keratin meal in group $\mathrm{K}$ was higher $(\mathrm{P}<0.01)$ than in the milk of those on soyabean oilmeal protein diet. Methionine supplementation increased the protein and fat contents in milk and this increase was slightly more pronounced in the milk of cows receiving keratin meal.

Experiment II, lasting from days 7 to 120 of life, was carried out on 5 groups of 10 calves fed concentrate mixtures containing soyabean oilmeal as the main source of protein in the control 
group, $\mathrm{C}$; in the experimental groups the oilmeal was substituted with different proportions of protein of keratin meal: $30 \%$ - group $\mathrm{K}_{30}, 60 \%$ - group $\mathrm{K}_{60}, 100 \%$ - group $\mathrm{K}_{100}$ or with equal amounts of keratin and blood meal - group $\mathrm{KB}_{50,50^{\circ}}$ In $1 \mathrm{~kg}$ all concentrate mixtures contained about $160 \mathrm{~g}$ of crude protein, $110 \mathrm{~g} \mathrm{BTJ}$ and $\mathrm{l}$ UFL and were fed ad libitum with 0.2 to $0.3 \mathrm{~kg} /$ day of meadow hay. No significant effect of keratin meal protein in the diet on daily gains or feed efficiency was found, however, calves in groups $\mathrm{C}$ and $\mathrm{K}_{30}$ had a tendency towards higher daily body weight gains than in the other groups.

KEY WORDS: feather keratin meal, dairy cattle, milk yield, milk composition, calf performance

\section{INTRODUCTION}

Feather keratin meal contains a high level of protein of low rumen degradability but its digestibility in the small intestine is quite high and depends on the methods and parameters of production (Aberibidge and Church, 1983; Blassi et al., 1991; Strzetelski et al., 1999). Keeping in mind, however, that the lysine and methionine contents in such protein are rather low and that of cysteine high, it is advisable to use it as a protein source in the diet in combination with other proteins supplementing limiting amino acids for absorption in the small intestine (Van Straalen and Tamminga, 1990; Harris et al., 1992; Ryś, 1993).

The aim of this study was to estimate milk yield and composition in high productive cows and calves performance fed diets containing domestically-produced feather keratin meals.

\section{MATERIAL AND METHODS}

Feather keratin meal was produced by hydrolysis of hen feathers at $150^{\circ} \mathrm{C}$ and 3 at. steam pressure for $30-40 \mathrm{~min}$, as described in a previous paper (Strzetelski et al., 1999).

The protein and energy value of fceds, proportion of ingredients in concentrate mixtures and daily ration for cows were determined according to IZ-INRA (1997) feeding standards using WINWAR ver. 1.3, WINMIX ver. 1.3 and INRA'tion ver. 1.23 (1996) software. The nutritive value of feeds was calculated based on the results of analysis for nutrient content, accepting coefficients of protein degradability in the rumen and intestinal digestibility of rumen undegraded protein for the majority of feed values given by INRA (1988), except of feather keratin meal and rapeseed expeller; these values were determined in a previous experiment (Strzetelski et al., 1999).

Gross energy was calculated according to the equation of Hoffmann et al. (1971). 


\section{Experiment on dairy cows}

Animals. The experiment was carried out on 48 Black-and-White Lowland cows selected from a herd of 480 cows 3 weeks before expected calving. The experimental animals were divided into 4 groups of 12 by an analogue method taking into account $\mathrm{HF}$ blood share, date of expected calving, lactation rank, milk yield at the peak of the last lactation, and body weight on day 70 before expected calving. The experiment was completed on day 84 of lactation.

Feeds and feeding. Basal feed rations for cows contained a combination of different proportions of various silages in the winter season; in the summer time fresh cut lucerne and maize were also included. The amount of feeds in daily rations for animals of all groups, depending on their availability during the experiment, did not exceed, in $\mathrm{kg} /$ day: lucerne silage, 16 ; whole plant barley silage with $20 \%$ lucerne, 13; whole plant barley silage with $50 \%$ lucerne, 30 ; sugar beet tops silage, 15; meadow hay, 1; fresh cut lucerne, 34; and fresh cut maize, 28.

A concentrate mixture $(\mathrm{CM})$ containing ground barley and wheat grain, wheat bran, rapeseed oilmeal, soyabean oilmeal and mineral mixture was given to all animals. The rations were supplemented with soyabean oilmeal in groups $S$ and $\mathrm{SM}$; in groups $\mathrm{K}$ and $\mathrm{KM}$ the soyabean oilmeal was substituted with feather keratin meal (assuming about $50 \%$ of crude protein in the diets from keratin) using a pelleted $(\phi 5 \mathrm{~mm})$ mixtures of feather keratin meal with rapeseed cake $\left(\mathrm{K}_{35}\right)$ and feather keratin meal with ground barley $(\mathrm{KB})$ (Table 1). Smartamine $\mathrm{M}^{\mathrm{TM}}$, produced by Rhône-Poulenc, containing $70 \%$ of methionine $90 \%$ protected from rumen degradation was added to the diet for groups SM and KM to cover the methionine deficiency in the diet.

The daily rations met requirement of cows for energy (UFL), protein digestible in the intestine (PDI), and minerals; the methionine deficiency in the rations was $20-25 \%$ PDIE and lysine only $2-5 \%$. The content of these amino acids in feeds was taken from INRAtion ver. 2.63 (1996) software.

The animals were fed individually 2 times per day, concentrate mixtures first and roughages afterwards; refusals were measured daily. Cows were milked twice a day and milk yield was recorded daily.

Sampling and analysis. Feeds and refusals were analysed for nutrient content according to AOAC (1990) recommendations. Acetic, butyric and lactic acid content in silage were estimated by GLC using Varian 30400 equipment, the $\mathrm{pH}$ of silages was measured potentiometrically. Daily milk samples were taken from each cow once per week and analysed for fat, protein and lactose contents using a Milkoscan apparatus.

Calculations. Daily nutrient intake was calculated as a weighted average taking into account the nutrient content of $1 \mathrm{~kg}$ of feed and intake for individual cows during the experimental period. 
Composition of concentrate mixtures and protein concentrate for cows, \%

Feed

Concentrate mixture, \%

\begin{tabular}{lccc}
\cline { 2 - 4 } & $\mathrm{CM}$ & $\mathrm{K}_{35}$ & $\mathrm{~KB}$ \\
\hline Ground barley grain & 36 & - & 35 \\
Ground wheat grain & 30 & - & - \\
Wheat bran & 10 & - & - \\
Rapeseeds oilmeal & 5 & - & - \\
Soyabean oilmeal & 15 & - & - \\
Hen feather keratin meal & - & 35 & 60 \\
Rapeseed expeller & - & 50 & - \\
Mineral mixture $\mathrm{M}_{1}{ }^{1}$ & 4 & - & - \\
Mineral mixture $\mathrm{M}_{2}{ }^{2}$ & - & 15 & 5 \\
\hline
\end{tabular}

1 - composition, \%: 15 - Premix B (Pozbac-Poznań, Poland), 6 - common salt, 18 - $\mathrm{NaHCO}_{3}$, $31-\mathrm{CaHPO}_{4} \cdot 2 \mathrm{H}_{2} \mathrm{O}, 8-\mathrm{MgO}, 22$ - wheat bran

in $1 \mathrm{~kg}, \mathrm{~g}$ : $150-\mathrm{Ca}, 57-\mathrm{P}, 71-\mathrm{Na}, 36-\mathrm{Cl}, 38-\mathrm{Mg}$; mg: $150-\mathrm{Cu}, 300-\mathrm{Mn}, 300-\mathrm{Zn}, 6-$ $\mathrm{Cu}, 6-\mathrm{J}$

2 - composition, \%: 50 - MMB (Pozbac-Poznań, Poland), $25-\mathrm{CaCO}_{3}, 25-\mathrm{HPO}_{4} \cdot 2 \mathrm{H}_{2} \mathrm{O}$ in $1 \mathrm{~kg}, \mathrm{~g}$ : $200,5-\mathrm{Ca}, 122,7-\mathrm{P}, 25-\mathrm{Na}, 38-\mathrm{Cl}, 23-\mathrm{Mg}$; mg: $665-\mathrm{Cu}, 1750-\mathrm{Mn}, 10-\mathrm{Co}$, $500-\mathrm{Zn} ;$ U.I. $1350-\mathrm{D}_{3}$

Statistical analysis was carried out according to the GLM procedure of SAS (1989) software using factorial analysis of variance. For the examined period of lactation (from day 1 to 84 ) fitted curvilinear milk yield in individual days of lactation, based on the multiple regression method, was obtained. The equation used was:

$y=A \cdot x^{\alpha} \cdot e^{a x}$ or in logarithmic form: $\ln y=\ln A+\alpha \ln x+a x$ where:

$\alpha=$ coefficient of linear correction between lny and $\ln x$

$\ln \mathrm{A}$ - displacement

$a=$ coefficient of linear correction for variable $x$, i.e. for lactation day.

\section{Experiment on calves}

The experiment was carried out on 50 Black-and-White Lowland bull-calves from days 7 to 120 of life, with an average $60 \%$ (from 37.5 to $87.5 \%$ ) of HF blood, divided into 5 groups of 10 , according to calving date and HF blood share, and was completed during 4 months.

Pelleted ( $\phi 5 \mathrm{~mm}$ ) concentrate mixtures for the respective groups of calves were fed during entire experimental period ad libitum plus 200-300 g/day/calf of meadow hay. During the milk feeding period the calves received $42 \mathrm{~kg}$ powder of the 
milk replacers Mlekopan H (Dairy Co., Góra, Poland) from day 7 to 30 and Primolac (Polmass, Bydgoszcz, Poland) from day 31 to 56 of age.

Calves were offered concentrate mixtures (Table 2) with different ratios of feather keratin meal protein or soyabean oilmeal, all mixtures contained about $16 \%$ crude protein; the control group, $\mathrm{C}$, was fed a mixture containing soyabean oilmeal protein as the main source of protein, which was substituted in the other groups by keratin meal protein: $\mathrm{K}_{30}, 30 \% ; \mathrm{K}_{60}, 60 \% ; \mathrm{K}_{100}, 100 \%$, or a mixture containing equal amounts of protein from keratin meal and blood meal, group $\mathrm{KB}_{50 / 50}$.

TABLE 2

Composition of concentrate mixtures for caives, $\%$

Groups

\begin{tabular}{lccccc}
\cline { 2 - 6 } Feed & $\mathrm{C}$ & $\mathrm{K}_{30}$ & $\mathrm{~K}_{f(0)}$ & $\mathrm{K}_{600}$ & $\mathrm{~KB}_{50 / 50}$ \\
\hline Ground barley & 35.4 & 41.6 & 48.7 & 52.6 & 52.7 \\
Ground wheat & 32.0 & 26.0 & 25.0 & 20.0 & 22.0 \\
Wheat bran & 16.0 & 18.0 & 14.0 & 18.0 & 16.0 \\
Soyabean oilmeal & 14.6 & 10.2 & 5.8 & - & - \\
Feather keratin meal & - & 2.2 & 4.5 & 7.4 & 3.7 \\
Blood meal & - & - & - & - & 3.6 \\
Mineral mixture' & 2.0 & 2.0 & 2.0 & 2.0 & 2.0 \\
\hline
\end{tabular}

1 - composition, \%: 25 - limestone, 15 - common salt, $35-\mathrm{CaHPO}_{4} \cdot 2 \mathrm{H}_{2} \mathrm{O}, 25$ - Premix CJ (Pozbac, Poznań, Poland)

in $1 \mathrm{~kg}, \mathrm{~g}: 71-\mathrm{Ca}, 61-\mathrm{P}, 58-\mathrm{Na}, 89-\mathrm{Cl}, 0.45$ - flavomycin;

mg: $185-\mathrm{Cu}, 357-\mathrm{Mn}, 7-\mathrm{Co}, 357-\mathrm{Zn}$;

I.U.: 1071 - vitamin $D_{3}$

Body weight, measured before the morning feeding as the average of two consecutive days, was controlled at the beginning of the experiment on day 7 , at the end of the milk period, day 56, and on days 80 and 120 of age.

The feeding regimen, feed evaluation and balancing of rations, based on analysed nutrient content, complied with IZ-INRA (1997) feeding standards. The nutritive value of milk replacer was calculated assuming that in the period of milk feeding the rumen of calves was not fully developed, hence the value of protein degradability coefficient in the rumen was null $(\mathrm{deg}=0)$ and the coefficient of intestinal digestibility (dsi) was 0.95 . The nutritive value of keratin feather meal and soyabean oilmeal was calculated accepting respective values of deg 0.30 and 0.52 , and dsi 0.74 and 0.94, respectively (Strzetelski et al, 1999); the respective values for the remaining feeds was according to INRA (1988).

Analyses. The chemical analysis of feeds was conducted using AOAC (1990) methods. Amino acids were analysed using Carlo-Erba 3A29 equipment after hy- 
drolysing samples with $6 \mathrm{~N} \mathrm{HCl}$, sulphur-containing amino acids were determined after oxidising with a formic acid and hydrogen peroxide mixture. Statistical analysis was carried out according to the GLM procedure of SAS (1989) software using factorial analysis of variance.

\section{RESULTS}

\section{Cows}

Data concerning differences between the groups of cows in HF blood share (from 48 to $62 \%$ ), body weight of cows on day 70 before calving (from 657 to $686 \mathrm{~kg}$ ) and lactation rank (from 3.3 to 3.6 ) did not differ significantly $(\mathrm{P}>0.05)$. The results of chemical analysis of feeds (Table 3 ) and their nutritive value estimated according to the IZ-INRA (1997) system (Table 4) indicate that roughage and concentrate feeds fed in this experiment were in the range of values observed for feeds being used in Poland.

Animals readily consumed feed rations and rarely left small refusals of roughages. Average intake of dry matter and UFL did not differ between the groups of animals but cows of groups $\mathrm{K}$ and $\mathrm{KM}$ consumed about $20 \%$ more crude protein and PDI $(\mathrm{P}<0.01)$ than those in the $\mathrm{S}$ and SM groups (Table 5). Intake of feather

TABLE 3

Chemical composition of feeds for cows, \%

\begin{tabular}{lccccccc}
\hline Feed & $\begin{array}{c}\text { Dry } \\
\text { matter }\end{array}$ & $\begin{array}{c}\text { Crude } \\
\text { protein }\end{array}$ & $\begin{array}{c}\text { Ether } \\
\text { extract }\end{array}$ & $\begin{array}{c}\text { Crude } \\
\text { fibre }\end{array}$ & Ash & pH & $\begin{array}{r}\text { Total acid } \\
\text { g/kg DM }\end{array}$ \\
\hline Maize silage & 32.63 & 3.38 & 1.69 & 7.81 & 2.14 & 4.10 & 94 \\
Lucerne silage & 21.67 & 2.94 & 1.24 & 8.46 & 1.93 & 5.30 & 39 \\
Sugar beet tops silage & 18.24 & 2.76 & 1.06 & 3.23 & 6.20 & 4.58 & 55 \\
Whole plant barley (80\%) & & & & & & & \\
and lucerne (20\%) silage & 44.61 & 4.14 & 1.04 & 21.70 & 2.97 & 4.80 & 45 \\
Barley and lucerne (1:1) silage & 28.61 & 3.15 & 1.21 & 8.24 & 2.06 & 4.90 & 74 \\
Green maize & 24.28 & 1.94 & 0.79 & 6.76 & 1.15 & & \\
Green lucerne & 14.19 & 2.52 & 0.55 & 4.53 & 1.35 & & \\
Meadow hay & 90.77 & 9.73 & 2.64 & 31.01 & 4.86 & & \\
Soyabean oilmeal & 87.07 & 42.13 & 1.81 & 6.55 & 6.62 & & \\
Hen feather koratin meal & 91.25 & 80.24 & 6.95 & - & 3.27 & & \\
Rapeseed cakc & 91.23 & 29.99 & 14.69 & 16.58 & 5.73 & & \\
Concentrate mixture CM & 87.91 & 17.20 & 2.23 & 4.97 & 4.65 & & \\
Keratin barley mixture KB & 80.64 & 52.30 & 4.97 & 2.68 & 1.60 & & \\
Protein concentrate $\mathrm{K}_{35}$ & 92.5 & 43.11 & 9.77 & 4.01 & 8.12 & & \\
\hline
\end{tabular}

' calculated taking into account percentage of acetic, butyric and lactic acids content in silage 
TABLE 4

Nutritive value of feeds for cows according to INRA system, in $1 \mathrm{~kg}$ of feed

\begin{tabular}{lccc}
\hline Feed & UFL & PDIN,g & PDIE, g \\
\hline Maize silage & 0.28 & 21 & 22 \\
Lucerne silage & 0.16 & 17 & 15 \\
Sugar beet tops silage & 0.14 & 18 & 16 \\
Whole plant barley $(80 \%)$ & & & \\
and lucerne (20\%) silage & 0.30 & 23 & 25 \\
Barlcy and luccrne (1:1) silage & 0.22 & 19 & 18 \\
Green maize & 0.22 & 12 & 17 \\
Green lucerne & 0.11 & 16 & 13 \\
Meadow hay & 0.65 & 51 & 69 \\
Soyabean oilmeal & 1.04 & 300 & 209 \\
Concentrate mixture CM & 0.99 & 117 & 321 \\
Keratin-barley mixture KB & 1.05 & 371 & 212 \\
Protein concentrate $\mathrm{K}_{35}$ & 0.85 & 289 & \\
\hline
\end{tabular}

TABLE 5

Average daily nutrients intake

\begin{tabular}{|c|c|c|c|c|c|}
\hline \multirow[b]{2}{*}{ Item } & \multicolumn{4}{|c|}{ Group } & \multirow[t]{2}{*}{ SEM } \\
\hline & S & SM & $\mathrm{K}$ & $\mathrm{KM}$ & \\
\hline Dry matter, kg & 19.98 & 19.90 & 19.84 & 19.81 & 0.24 \\
\hline Crude protein, $\mathrm{kg}$ & $3439^{\mathrm{A}}$ & $3469^{A \cdot d}$ & $4143^{\mathrm{Bb}}$ & $4152^{\mathrm{Bb}}$ & 42.8 \\
\hline PDIN, $\mathrm{g}$ & $2289^{\wedge a}$ & $2311^{\mathrm{Aa}}$ & $2750^{\mathrm{Bb}}$ & $2753^{\mathrm{Bb}}$ & 28.9 \\
\hline PDIE, $\mathrm{g}$ & $2071^{\text {Aa }}$ & $2069^{A u}$ & $2445^{\mathrm{Bb}}$ & $2446^{\mathrm{Bb}}$ & 24.7 \\
\hline UFL & 18.92 & 18.74 & 18.31 & 18.38 & 0.23 \\
\hline
\end{tabular}

${ }^{a, b}-\mathrm{P} \leq 0.05 ;{ }^{A . B}-\mathrm{P} \leq 0.01$

keratin meal in both groups was $1.88 \mathrm{~kg} /$ day/cow (on average 1.50 with $\mathrm{KB}$ and about 2.78 with $\mathrm{K}_{35}$ mixtures) and keratin meal protein in groups $\mathrm{K}$ and $\mathrm{KM}$ was about $36 \%$, while rumen undegradable protein was $23 \%$ of total crude protein. In groups S and SM, crude protein of soya origin was about $40 \%$ of total crude protein, whereas in groups $\mathrm{K}$ and $\mathrm{KM}$ only about $7 \%$. The intake of crude fat was $203 \mathrm{~g} /$ day/cow higher in groups $\mathrm{K}$ and $\mathrm{KM}$ than in S and SM.

Daily and total milk production was similar in all groups of cows $(P>0.05)$, however, there was a tendency towards lower (6-7\%) production in group $\mathrm{S}$ than in the remaining groups. The rate of lactation pattern from day 1 to 84 (Figure 1) demonstrated significantly lower $(\mathrm{P}<0.01$ or $\mathrm{P}<0.05)$ daily milk production in group $\mathrm{S}$ than in the remaining groups, but only in the maximal production period from days 22 to 36 of lactation. 


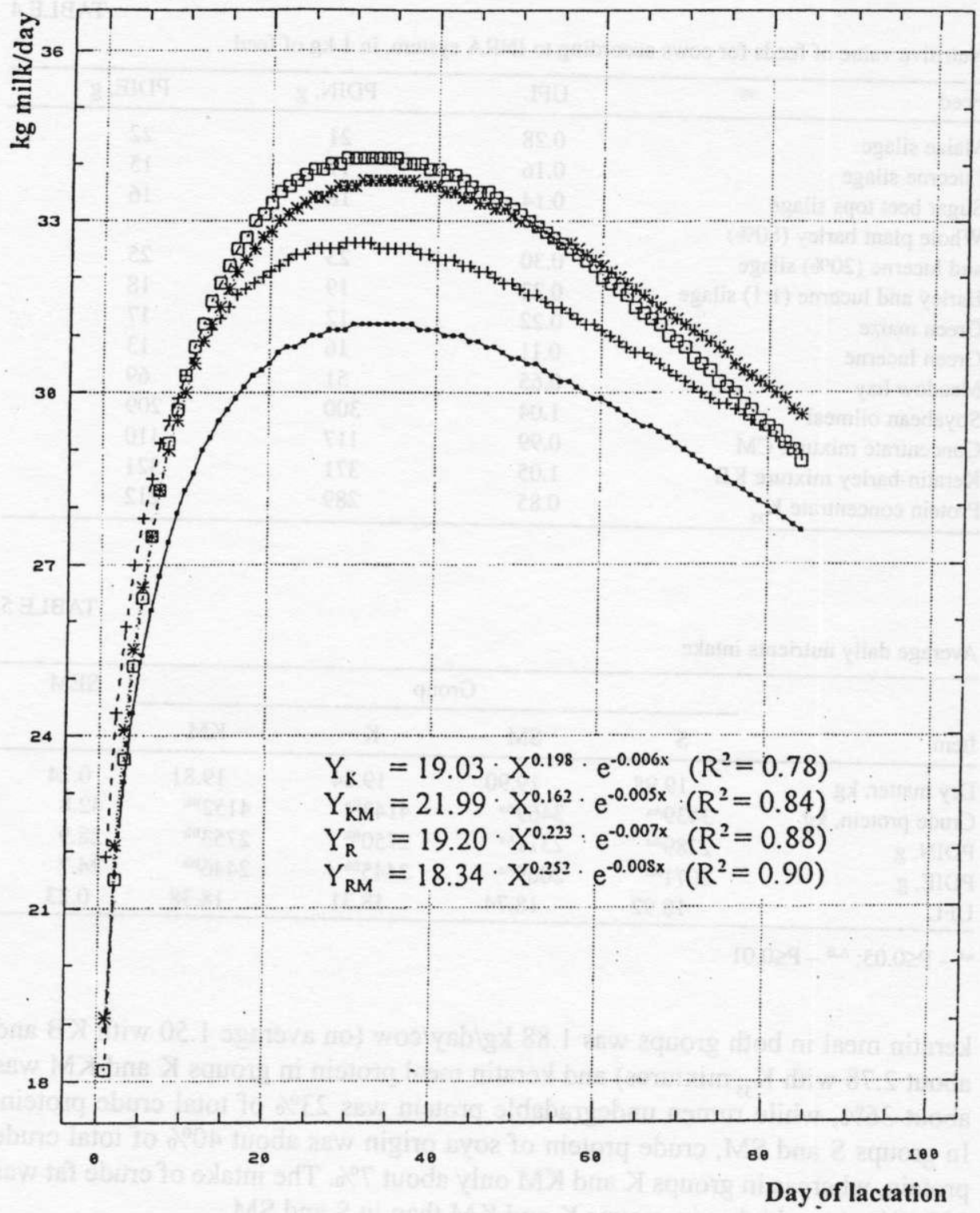

Figure 1. Daily milk yield

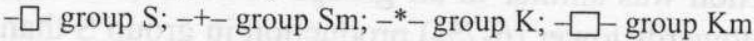


Addition of methionine to the diets induced milk production, particularly in group SM in comparison with group S (Table 6). The content of protein in milk from cows fed diets with methionine was also slightly higher than in the remaining animals, this difference was more pronounced in cows fed feather keratin meal $(1 \mathrm{~g})$ than plant origin protein $(0.3 \mathrm{~g}$ of $1 \mathrm{~kg}$ milk). The addition of methionine also increased the fat content of milk. The lactose content in milk from cows of the $\mathrm{S}$ groups was lower than in the other groups $(\mathrm{P}<0.05)$.

TABLE 6 Total and daily milk production (average of daily measurements) and composition (average of weekly measurements)

\begin{tabular}{lccccc}
\hline & \multicolumn{4}{c}{ Group } & SEM \\
\cline { 2 - 5 } Item & $\mathrm{S}$ & $\mathrm{SM}$ & $\mathrm{K}$ & $\mathrm{KM}$ & \\
\hline Total milk production, $\mathrm{kg}$ & 2470 & 2588 & 2646 & 2652 & 36.6 \\
Daily milk production, $\mathrm{kg}$ & 29.4 & 30.8 & 31.5 & 31.6 & 0.40 \\
Milk fat, \% & $3.93^{\mathrm{Aa}}$ & $4.11^{\mathrm{Bb}}$ & $3.98^{\mathrm{Au}}$ & $4.19^{\mathrm{Bb}}$ & 0.01 \\
Milk protein, $\%$ & $3.14^{\mathrm{ABb}}$ & $3.17^{\mathrm{Bb}}$ & $3.05^{\mathrm{Aa}}$ & $3.15^{\mathrm{ABb}}$ & 0.01 \\
Milk lactose, $\%$ & $4.50^{\mathrm{Aa}}$ & $4.69^{\mathrm{Bb}}$ & $4.68^{\mathrm{Bb}}$ & $4.66^{\mathrm{Bb}}$ & 0.02 \\
Fat production, $\mathrm{kg}$ & $97.0^{\mathrm{Aa}}$ & $106.5^{\mathrm{ABb}}$ & $105.4^{\mathrm{Aubb}}$ & $111.0^{\mathrm{Bb}}$ & 1.37 \\
Protein production, $\mathrm{kg}$ & $77.6^{\mathrm{Aa}}$ & $82.1^{\mathrm{Aabb}}$ & $80.8^{\mathrm{Aath}}$ & $83.4^{\mathrm{Ab}}$ & 1.00 \\
\hline
\end{tabular}

$a, b-P \leq 0.05 ;{ }^{A} \cdot \mathrm{B}-\mathrm{P} \leq 0.01$

During the whole lactation period, cows fed diets supplemented with methionine produced milk with only slightly, but not significantly, higher levels of protein and fat, lactose only for cows receiving soyabean oilmeal (Figure 2). Cows fed diets containing feather keratin meal (K and $\mathrm{KM}$ ) used less dry matter and energy for production of $1 \mathrm{~kg}$ of milk, but more crude protein and protein digested in the small intestine (Table 7) than on the rations containing only plant origin protein (S and SM)

\section{Calves}

The level of crude protein (about 16\%) and energy (about $0.99 \mathrm{UFL} / \mathrm{kg}$ ) was similar in all concentrate mixtures; $1 \mathrm{~kg}$ of mixtures contained $880 \pm 2.0 \mathrm{~g} \mathrm{DM}$, $1.0 \pm 0.01 \mathrm{UFL}, 110 \pm 2 \mathrm{~g}$ PDIN and $112 \pm 3 \mathrm{~g}$ PDIE. The protein of soyabean oilmeal contained three times and blood meal two times more methionine than protein of feather keratin meal, however, the sum of sulphur-containing amino acids, methionine + cystine, due to the high cystine content, was about two times higher in feather keratin meal protein, but the lysine content was much lower than in the other feeds (Table 8). 


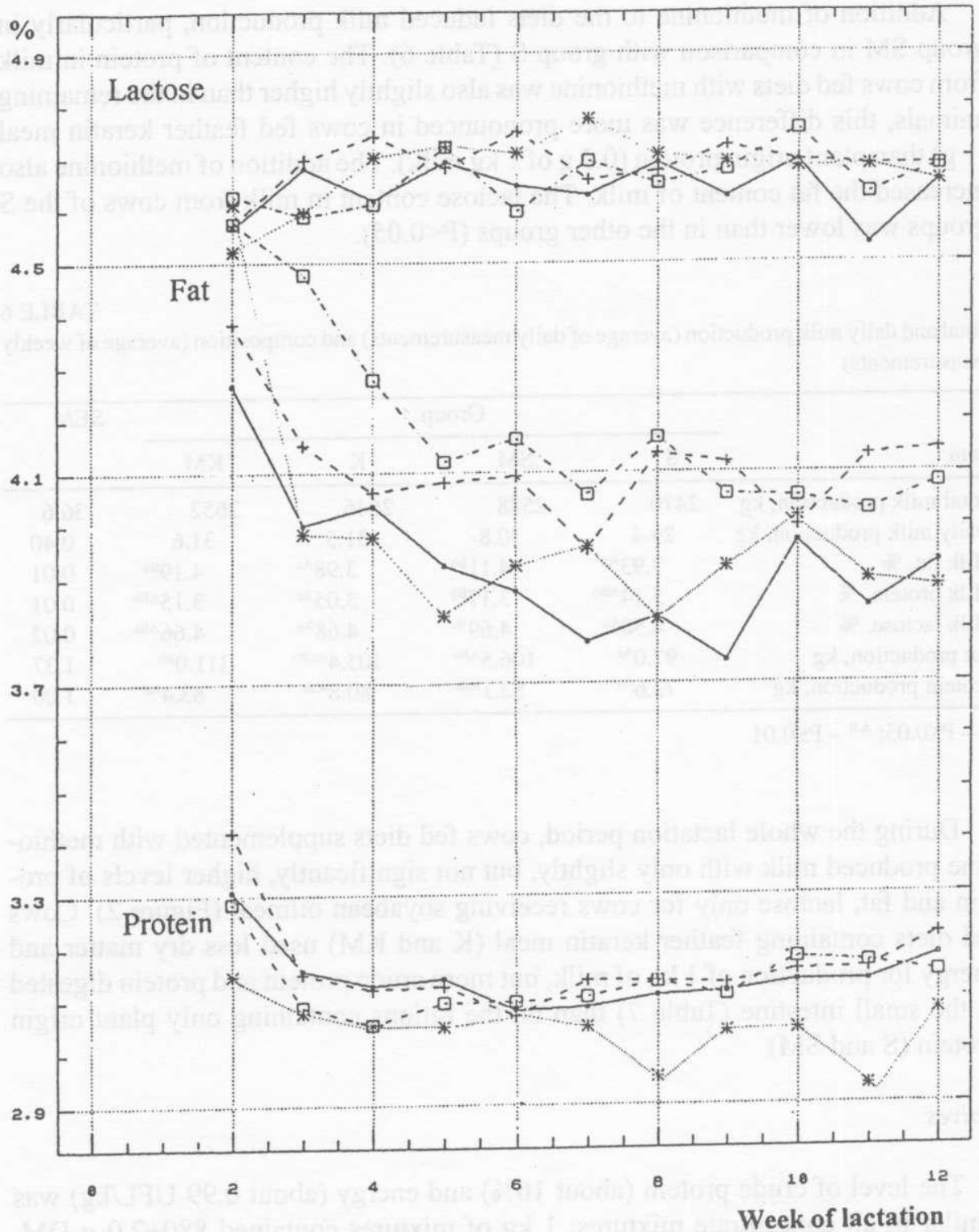

Figure 2. Lactose, fat and protein content in milk

$-\square$ - group $\mathrm{S}$; -+- group Sm; -*-group $\mathrm{K} ;-\square-$ group $\mathrm{Km}$ 
Daily intake of nutrients and concentrate mixtures did not differ $(\mathrm{P}>0.05)$ between the groups, although there was a tendency towards slightly higher, by about $10 \%$, concentrate intake by calves in groups $\mathrm{C}$ and $\mathrm{K}_{30}$. Daily body weight gains and intake of concentrate mixtures per $1 \mathrm{~kg}$ of body gain were not significantly different between the groups (Table 9), although the body gains for the whole experimental period were about $6 \%$ higher in $\mathrm{C}$ and $\mathrm{K}_{30}$ than in the remaing groups.

TABLE 7

Feed and nutrients conversion per $1 \mathrm{~kg}$ milk

\begin{tabular}{lccccc}
\hline & \multicolumn{4}{c}{ Group } & SEM \\
\cline { 2 - 5 } Item & $\mathrm{S}$ & $\mathrm{SM}$ & $\mathrm{K}$ & $\mathrm{KM}$ & \\
\hline Plant origin concentrate meal, $\mathrm{kg}$ & $0.29^{\mathrm{A}}$ & $0.28^{\mathrm{A}}$ & $0.20^{\mathrm{B}}$ & $0.19^{\mathrm{B}}$ & 0.01 \\
Feather keratin meal, kg & - & - & 0.06 & 0.06 & - \\
Dry matter, kg & $0.68^{\mathrm{Aa}}$ & $0.65^{\mathrm{Ab}}$ & $0.63^{\mathrm{B}}$ & $0.63^{\mathrm{B}}$ & 0.01 \\
Crude protcin, & $117.0^{\mathrm{A}}$ & $112.7^{\mathrm{A}}$ & $132.2^{\mathrm{B}}$ & $126.5^{\mathrm{B}}$ & 1.19 \\
PDI, g & $70.5^{\mathrm{BbC}}$ & $67.2^{\mathrm{bC}}$ & $78.0^{\mathrm{Aa}}$ & $74.3^{\mathrm{AaB}}$ & 0.66 \\
UFL & $0.64^{\mathrm{Aa}}$ & $0.61^{\mathrm{Abb}}$ & $0.58^{\mathrm{BbC}}$ & $0.58^{\mathrm{Ca}}$ & 0.01 \\
\hline
\end{tabular}

a.b.c $-P \leq 0.05 ;$ A.B.C $-P \leq 0.01$

TABLE 8

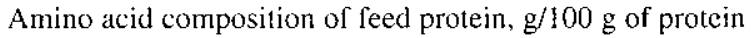

\begin{tabular}{lccc}
\hline & & \multicolumn{3}{c}{ Fced } & \\
\cline { 2 - 4 } Amino acid & feather keratin meal & blood meal & soyabean oilmeal \\
\hline Asp & 6.08 & 10.33 & 10.28 \\
Thr & 4.01 & 4.47 & 3.83 \\
Ser & 8.72 & 4.60 & 3.72 \\
Glu & 11.61 & 9.91 & 17.68 \\
Pro & 10.27 & 3.81 & 4.00 \\
Gly & 7.91 & 4.26 & 3.94 \\
Ala & 6.31 & 7.67 & 3.20 \\
Val & 7.13 & 8.13 & 4.51 \\
Ile & 4.83 & 1.00 & 4.29 \\
Leu & 8.44 & 13.17 & 7.69 \\
Tyr & 2.33 & 1.76 & 2.83 \\
Phe & 4.37 & 6.87 & 3.66 \\
His & 1.84 & 5.93 & 3.64 \\
Lys & 3.30 & 9.19 & 6.68 \\
Arg & 5.96 & 3.50 & 9.39 \\
Cys & 4.84 & 1.12 & 0.87 \\
Met & 0.51 & 1.05 & 1.46 \\
\hline
\end{tabular}


TABLE 9

Body liveweight and daily body gain of calves, and feed efficiency

\begin{tabular}{|c|c|c|c|c|c|c|}
\hline \multirow[b]{2}{*}{ Item } & \multicolumn{5}{|c|}{ Group } & \multirow[t]{2}{*}{ SEM } \\
\hline & $\mathrm{C}$ & $\mathrm{K}_{30}$ & $K_{(x)}$ & $K_{1(x)}$ & $\mathrm{K}_{50 / 50}$ & \\
\hline \multicolumn{7}{|l|}{ Body liveweight, $\mathrm{kg}$} \\
\hline initial & 48.3 & 46.4 & 47.6 & 48.3 & 47.4 & 0.78 \\
\hline at the day 56 of life & 74.4 & 70.8 & 71.6 & 70.3 & 71.2 & 1.07 \\
\hline final, at the day 120 of life & 141.4 & 140.6 & 136.2 & 138.2 & 134.8 & 12.0 \\
\hline \multicolumn{7}{|l|}{ Average daily body gain, $\mathrm{g}$} \\
\hline till 56 day of life & 553 & 498 & 490 & 449 & 486 & 20.7 \\
\hline from 57 to 120 day of life & 1047 & 1091 & 1010 & 1058 & 994 & 19.0 \\
\hline for whole experimental period & 824 & 834 & 784 & 794 & 773 & 12.5 \\
\hline \multicolumn{7}{|l|}{$\begin{array}{l}\text { Feed utilisation for whole } \\
\text { experimental period, per } 1 \mathrm{~kg} \text { of gain }\end{array}$} \\
\hline concentrate mixture, $\mathrm{kg}$ & 2.55 & 2.53 & 2.40 & 2.46 & 2.43 & 0.04 \\
\hline dry matter, $\mathrm{kg}$ & 2.88 & 2.84 & 2.81 & 1.83 & 2.82 & 0.04 \\
\hline crude protein, g & 550 & 543 & 536 & 549 & 548 & 7.6 \\
\hline PDI, $\mathrm{g}$ & 399 & 402 & 401 & 402 & 407 & 5.4 \\
\hline UFL & 3.26 & 3.18 & 3.16 & 3.17 & 3.16 & 0.05 \\
\hline
\end{tabular}

\section{DISCUSSION}

Formulation of rations for cows according to the INRA system (1988) in such a way that $50 \%$ of the protein is derived from feather keratin meal appeared to be difficult since feather meal contains a high level of protein of low degradability in the rumen. Such a high proportion of protein of keratin origin in crude protein of total rations could decrease microbial protein yield in the rumen related to the yield assumed by the INRA (1988) system (Waltz et al., 1989; Clark et al., 1992; Cunningham, 1994). This was the reason that the proportion of keratin meal protein in crude protein of the total ration could not exceed $36 \%$, and of rumen undegraded protein (PDIA) about $23 \%$, which in our experiment resulted in an about $20 \%$ increase of daily intake of crude protein and PDI compared to rations containing only plant-origin protein, but had no significant effect on daily milk yield. So, it seems that all rations were formulated properly according to INRA system recommendations.

Different responses have been obtained in experiments with milk cows fed differentiated proportions of rumen undegraded protein of animal origin. Hoover and Stokes (1991) demonstrated that increased levels of undegradable protein in a ration of high fermentability did not effect milk production, allowing for high utili- 
sation of nitrogen degradable in the rumen. However, Palmquist and Weiss (1994) did not find significant increase in milk production in high productivity cows fed rations with higher levels of crude protein containing a large proportion of undegradable protein. Similarly, when Waltz (1989) fed cows rations containing 50\% protein derived from feather meal or feather meal with blood meal (1:1) higher milk production was not obtained. Johnson et al. (1994) also found no increase in total milk production but demonstrated high milk production in the early lactation period in cows fed rations containing animal-origin meals. Erasmus and Botha (1994) obtained lower milk production in cows fed rations containing less undegradable protein than recommended by NRC (1989). Bernard and Kelly (1990) and Grummer and Luck (1994) increased the proportion of undegradable to degradable protein in rations for cows by adding different meals of animal origin and obtained higher milk production, particularly around the peak of lactation. The slightly higher milk production over the whole experimental period in cows fed rations containing keratin meal protein compared to cows fed only plant-origin protein or supplemented with protected methionine could have been caused by higher passage of amino acids into the small intestine (Grummer and Luck, 1994). Moreover, it can not be excluded that the higher protein concentration (about 20\% in $\mathrm{DM}$ ) in rations containing keratin meal than those containing only plant-origin protein (about $17 \%$ in DM) fed in the early lactation period, when intake was limited, could advantageously affect covering of the protein requirement for cows in the period of maximal milk production (Palmquist and Weiss, 1994). Patton (1996) reported that the addition of methionine to rations deficient in this amino acid increased milk production at the peak of lactation. Feeding cows feather keratin meals, which led to higher milk production (Linzel and Peaker, 1971), or rations supplemented with methionine was also beneficial in terms of higher milk lactose levels. It does not seem that a higher intake of fat with a ration containing feather keratin meal than in the remaining rations affected milk yield since the energy value of all rations calculated according to the IZ-INRA (1997) system was similar.

The different reactions of cows on methionine supplementation to the rations manifested as a higher increase of protein content in the milk of cows receiving feather keratin meal with ration $(1 \mathrm{~g} / \mathrm{kg}$ of milk) than fed only plant-origin protein $(0.3 \mathrm{~g} / \mathrm{kg}$ of milk) point to the possibility of modifying the profile of amino acids available for absorption in duodenal digesta (Armentano et al., 1994). Thomas and Martin (1988) and Rulquin (1992) also demonstrated that a postruminal casein infusion increased milk production and the protein content of milk (from 1.1 to $1.5 \mathrm{~g} / \mathrm{kg}$ ) due to increased protein available for absorption and amino acid delivery. Similar results were obtained by Patton (1996) and Velle et al. (1997) who supplemented diets with protected methionine which improved amino acid composition in duodenal digesta. 
The simultaneous increase of protein and fat concentrations in the milk of cows fed diets supplemented with methionine in the present experiment points to a correlation between these components, confirming such a relationship reported by Czaja (1990). Ryś et al. (1982) and Patton (1996) suggest that methionine is involved in the mammary gland fat metabolism system in cows and increases microbial activity in the rumen affecting fat production in milk. According to Ryś (1993) cows fed diets supplemented with feather keratin meal produced more milk with a higher fat content, but it could be presumed that a higher protein content in the diets with keratin meal improved fat utilisation, which was reflected in a higher fat content in milk (Palmquist and Weiss, 1994).

The amino acid composition of the blood meal protein used in the present study was similar to that given by Palmquist and Weiss (1994), whereas the feather meal protein contained more lysine and histidine. Differentiated amino acid composition of the feeds used did not significantly affect body weight gains of calves nor feed efficiency, however, there was a tendency towards a slightly higher calf performance on diet $\mathrm{K}_{30}$ and a lower one on $\mathrm{KB}_{50 / 50}$

The slightly lower daily body gain of calves over the whole experimental period in the groups receiving diets containing concentrate mixtures with more than $30 \%$ of protein from keratin meal could be a consequence of lower feed intake probably caused by the characteristic smell of keratin meal. Furthermore, one could expect greater differences in daily gains between the groups, particularly in the period of liquid feeding, caused by lower amino acid absorption of rumen undegraded keratin meal protein in comparison with the digestibility of soyabean meal protein (Strzetelski et al., 1999). However, between days 57 and 120 the body gain of $\mathrm{M}_{30}$ calves receiving $30 \%$ of protein from keratin meal were slightly greater than in the remaining groups, suggesting that the mixture better met the requirements for degradable and undegradable protein of older calves with more developed rumen functions. Replacement with an equivalent amount of keratin meal up to $2.2 \%$ in the concentrate mixture (up to $30 \%$ of dietary protein), despite lysine and methionine deficiency, had no negative effect on calf performance but a higher level of keratin or even its mixture with blood meal protein generated lower body gain and feed efficiency.

\section{CONCLUSIONS}

In conclusion, it can be stated that, despite its lysine and methionine deficiency, hen feather keratin meal can be used as a satisfactory alternative protein source in feeding dairy cows and, to some extent, calves. 


\section{REFERENCES}

Aderibigde A.O., Church D.C., 1983. Feather and hair meals for ruminants. III. Relationship between enzymatic or in vitro rumen digestibility and in vivo digestibility of diets containing feather or hair meals. J. Anim. Sci. 57, 483-494

AOAC, 1990. Association of Official Analytical Chemists. Official Methods of Analysis. 15th Edition. Arlington, VA

Armentano L.E., Swain S.M., Duckarme G.A., 1993. Lactation response to ruminally protected methionine and lysine at two amounts of ruminally available nitrogen. J. Dairy Sci. 76, 2963-2969

Bernard J.K., Kelly F.M., 1990. Influence of cottonseed meal or meat and bone meal additions to diets containing wheat middling fed to lactating cows. J. Dairy Sci. 73, Suppl.1, 170 (Abstr)

Blassi D.A., Klopfenstein T.J., Drouillard J.S., Sindt S.H., 1991. Hydrolysis time as a factor affecting the nutritive value of feather meal and feather meal-blood meal combinations for groving calves. J. Anim. Sci. 69, 1272-1278

Clark J.H., Klusmeyer T.H., Cameron M.R., 1992. Microbial protein synthesis and flows of nitrogen fractions to the duodenum of dairy cows. J. Dairy Sci. 75, 2304-2323

Cunningham K.D., Cecava M.J., Johnson T.R., 1994. Flows of nitrogen and amino acids in dairy cows fed diets containing supplementat feather meal and blood meal. J. Dairy Sci. 77. 3666-3675

Czaja H., 1990. Utilisation of milk protein yield for the selection of the domestic Black-and-White cattle (in Polish). Dissertation. Research Institute of Animal Production, Kraków (Poland)

Erasmus L.J.. Botha P.M., 1994. Effect of protein source on ruminal fermentation and passage of amino acids to the small intestine of lactating cows. J. Dairy Sci. 77, 3655-3665

Grummer R.R., Luck M.L., 1994. Lactational performance of dairy cows fed raw soybean with or without animal by-product proteins or roasted soybcans. J. Dairy Sci. 77,1354-1359

Harris Jr. B., Dorminey D.E., Smith W.A., Van Horn H.H., Wilcox C.J., 1992. Effects of feather meal at two protein concentrations and yeast culture on production parameters in lactating dairy cows. J. Dairy Sci. 75, 3524-3530

Hoffmann L., Schicmann R., Jentch W., 1971. Energetische Verwertung der Närhstoffe in Futterrationen. In: Energetische Futterbewertung und Energiennormen. VEB Dte Landw. Verlag, Berlin (DDR), pp.118-167

Hoover W.H., Stokes S.R., 1991. Balancing carbohydrates and proteines for optimum rumen microbial yield. J. Dairy Sci. 74, 3630-3644

INRA, 1988. Institut National de la Rechearche Agronomique. Alimentation des Bovins, Ovins, Caprins (R. Jarrige, Editor). Paris, pp. 135-184

IZ-INRA, 1997. Research Institute of Animal Production. Standards of Cattle, Sheep and Goats Feeding (in Polish). Omnitech Press, Warszawa (Poland)

Johnson T.R., Cecava M.J., Sheiss E.B., Cunningham K.D., 1994. Addition of ruminally degradable crude protein and branched-chain volatile fatty acids to dicts containing hydrolyzed feather meal and blood meal for lactating cows. J. Dairy Sci. 77, 3676-3682

Linzel J.L., Peaker M., 1971. Mechanism of milk secretion. Physiol. Rev. 51, 564-571

NRC, 1989. National Research Council. Nutrient Requirements of Dairy Cattle. 6th revised Edition. National Academy of Sciences. Washington, DC

Palmquist D.L., Weiss W.P., 1994. Blood and hydrolyzed feather meals as sources of undegradable protein in high fat diets for cows in early lactation. J. Dairy Sci. 77, 1630-1643

Patton R.A., 1996. Methionine nutrition in dairy cows remains difficult. Feedstuffs 68 (11), 13-14

Rulquin H., 1992. Interets et limites d'un apport de methionine et de lysine dans 1'alimentation des vaches laitières. INRA Prod. Anim. 5, 29-36 
Ryś R., 1993. Keratins from offals as a source of feed protein (in Polish). Biul. inf. Inst. Zoot. 31 (3-4), 35-45

Ryś R., Strzetelski J., Stasiniewicz T., Sroka M., 1982. Effect of supplementation of synthetic DL-methionine and hydroxy-methionine-analogue to cow ration on milk yield, and fat and protein content in milk (in Polish). Rocz. Nauk. Zoot. 9 (1), 157-166

SAS, 1989. Users Guide, Statistics, version 6, SAS, Inst. Inc. Cary, NC

Strzetelski J.A. Kowalczyk J., Niwińska B., Bilik K., Maciaszek K., 1999. Nutritive value of feather keratin meals for ruminants. J. Anim. Feed Sci. 8, 387-393

Thomas P.C., Martin P.A., 1988. The influence of nutrient balance on milk yield and composition. In: W. Haresign, D.J.A. Cole (Editors). Nutrition and Lactation in the Dairy Cow. Butterworth, London, pp. 97-118

Van Straalen W.M., Tamminga S., 1990. Protein degradation of ruminant diets. In: J. Wieseman, D.J.A. Cole (Editors). Feed Evaluation. Butterworth, London, pp. 55-72

Velle W., Sjaastad Qt.V., Aulie A., Gromset D., Feigenwinter K., Framstad T., 1997. Rumen escape and apparent degradation of amino acids after individual intraruminal administration to cows. J. Dairy Sci. 80, 3325-3332

Waltz D.M., Stern M.D., Illg D.J., 1989. Effect of ruminal protein degradation of blood meal and feather meal on the intestinal amino acid supply to lactating cows. J. Dairy Sci. 72, 1509-1518

\section{STRESZCZENIE}

\section{Wplyw skarmiania dawek zawierających mączkę keratynową z piór na wydajność i sklad mleka krów oraz przyrosty masy ciala i wykorzystanie paszy przez cielęta}

W doświadczeniu przeprowadzonym na 48 krowach podzielonych na 4 grupy, w okresie od wycielenia do 84 dnia laktacji, skarmiano dawki zawierające białko pochodzenia roślinnego bez (grupa S) lub z dodatkiem chronionej metioniny (SM) oraz dawki zawierające mączkę keratynową $\mathrm{z}$ piór bez $(\mathrm{K})$ lub $\mathrm{z}$ dodatkiem chronionej metioniny (KM). Białko mączki keratynowej stanowito około $36 \%$, a białko keratynowe nie rozkładalne w żwaczu $23 \%$ białka ogólnego dawki. Krowy otrzymujące mączkę keratynową pobicrały istotnie więcej białka ogólnego i BTJ $(\mathrm{P}<0,01)$ niż żywione dawkami zawicrającymi białko pochodzenia roślinnego. Pobranie suchej masy pasz i energii oraz średnia dzienna produkcja mleka za cały okres doświadczenia były podobne we wszystkich grupach, ale w okresie około szczytowym, od 22 do 36 dnia laktacji, zaznaczył się korzystny wpływ dodatku metionimy $(\mathrm{P}<0,05)$ oraz mączki keratynowej $(\mathrm{P}<0,01)$ na dzienną wydajność mleka. Zawartość laktozy w mleku krów otrzymujących poekstrakcyjną śrutę sojową była mniejsza $(\mathrm{P}<0,01)$ niż krów pozostałych grup. Dodatek do dawck chronionej metioniny zwiększył zawartość tłuszczu i białka w mleku, co uwydatniło się w większym stopniu przy skarmianiu dawki z mączką keratynową niż z białkiem pochodzenia roślinnego.

W doświadczeniu na 5 grupach po 10 cieląt, w wicku od 7 do 120 dnia życia, skarmiano mieszanki treściwe zawierające poekstrakcyjną śrutę sojową jako główne źródło białka, w grupie kontrolnej - C, które zastępowano stopniowo w grupach doświadezalnych białkiem mączki keratynowej: $30 \%$ - grupa $\mathrm{K}_{30}, 60 \%-\mathrm{K}_{60}, 100 \%-\mathrm{K}_{1000}$ lub mieszanką zawierająca jednakowe ilości białka mączki keratynowej i mączki z krwi $-\mathrm{KB}_{50: 50}$. Wszystkie mieszanki treściwe zawieraly podobna ilość białka ogólnego (16\%) i cnergii ( $1 \mathrm{JPM} / \mathrm{kg}$ ) i były skarmiane do woli $z$ dodatkiem $0,2-0,3 \mathrm{~kg} /$ dzień siana łąkowego. Przyrosty masy ciała, zużycie mieszanki treściwej i składników pokarmowych na $1 \mathrm{~kg}$ przyrostu nie różniły się istotnie pomį̧dzy grupami. $\mathrm{U}$ cieląt grupy $\mathrm{C} \mathrm{i} \mathrm{K}_{30}$ stwierdzono jednakże tendencję do większych przyrostów masy ciała niż cieląt z pozostałych grup. 